MOV 501967
$\ldots$

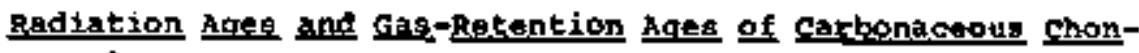
drites and of Unguilibrated ordinary ghomartites

$$
\text { D. Heymann* and E. Mazor** - }
$$

Enrico Fermi Institute, Univeraity of chicago, chicago, Ilitrois, U. s. A.

- Present addregs: Department of ceology. Rice Univeraity, Hougton; Texag, U. S, A.

thon laave of absence from the Ingael atonte Energy comnission and the Heizmann Institute of science, Rehovoth, 2ar ael

\section{REVTSED ABSTRACT}

Ho, Ne, and Ar have been determined by mago-spectromatiry in 25 carbonaceous chondrites, and in 12 unequilibrated ordinary chondrites. The oceurrence of primordial inert gases, and the passibility of severe diffusion logses

$$
600->8 z+7.5
$$

Cont-6000\%:

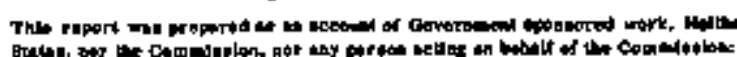

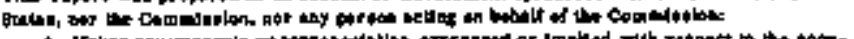

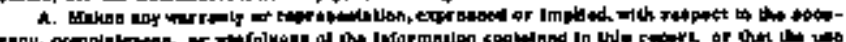

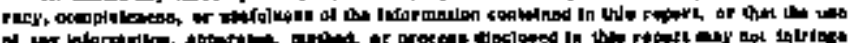

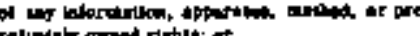

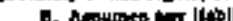

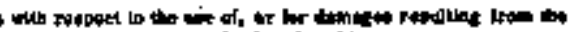

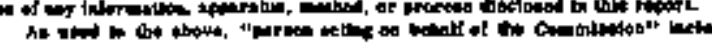

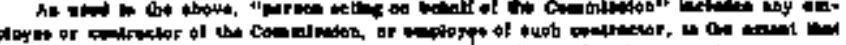

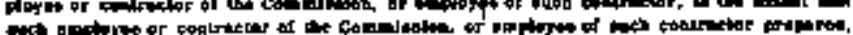

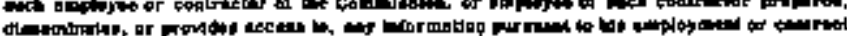

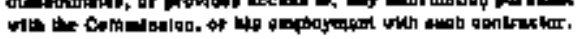

$-$

in certain carbonaceous chondrites leats to the following considierations: 1) 0 , Th-lke agas cannot be estimated for the cl and c2 - types carbonaceovs chondr1tes; 2) only "minimum" ${ }^{3}$ Ha gages can br estimated for the cl and c2types carbonaceous chondiriter, and 3) ${ }^{36}$ Ax -age cannot. be estimated for any of the meteorites, except karoonda. The radiation ages of the carbonaceouk chondrites and of the voc ard not grossly diffarent from those of the ordinary chondrites. However, the following trends can be noted, 1) the aglea of the $c l$ and $c 2$ carbonaceous chondrites are on the average shorter than those of the ordinary chondrites; none of the former is groater than 15 Hyr: 2) four, perbaps five c2 carbonaceous chondrited, Boriskimo. cold Bokkeve1d, Heripura, Nawapalt, and Hogoya cone from a single collison 0.1=0.6 Myr ago, with the most likely dato of $0.2 \pm 0.1 \mathrm{myr}$.

There is a rough correlation botween the-types of carbonaceous chondrites and $\mathrm{K}-\mathrm{Ar}$ agess cl meteoxtteo 


\section{DISCLAIMER}

This report was prepared as an account of work sponsored by an agency of the United States Government. Neither the United States Government nor any agency Thereot, nor any of their employees, makes any warranty, express or implied, or assumes any legal liability or responsibility for the accuracy, completeness, or usefulness of any information, apparatus, product, or process disclosed, or represents that its use would not infringe privately owned rights. Reference herein to any specific commercial product, process, or service by trade name, trademark, manufacturer, or otherwise does not necessarily constitute or imply its endorsement, recommendation, or favoring by the United States Government or any agency thereof. The views and opinions of authors expressed herein do not necessarlly state or reflect those of the United States Government or any agency thereof. 


\section{DISCLAIMER}

Portions of this document may be illegible in electronic image products. Images are produced from the best available original document. 
(C3 + c4) meteoriten of 2-4 Gyx.

The grant majoxity of the voc geam to have cooled to below 200-300 $\mathrm{C}$ wome $2.5-4.5$ Gyr ago. Anong the $\mathrm{L} 3$ shondrites there is a rough anti-corralation betwen age and degree of recryatalization. This mens to imply that the more highly equilibrated chondrited core from greater appth ineide the parent object than the woc.

Badiatjon bges and Gass-Betention Ages of carbonaceoule chondrites and of thecuilibrated oxdinary chondritan

\section{Haymank and E. Hozort*}

- Present addreges Dopartment of Geology, Rice onivarsity, Fouston, Texas, J. S. A.

t* on Lave of abence from the Ierael Atoric Energy conrisuion and the Woizmann Inetitute of seience, Rehovoth, Iorael

ImRODUCTION

The inert gobeg have been measured in recent years in several hundred oxdinary chondrites, and ubeful information has oon obtained pertaining to their oxigin from radiation and gus-rotontion agos artimated frow euch duta.
It has been noted proviously that the carbonas a chomdrites generally show lower $\mathrm{K}-\mathrm{Ar}$ ages than the ordinary chondrites. Most authore have concluded that the carbonsceous chondrites nearly alwaye euffered serious $40_{\mathrm{Ar}}$ diffusion lasnes (cf. Msos [1]). It has also been noted that certain carbonaceous chondrites ghow unurually low radiation agen. In the cast of cold gokkoveld, ANDERS [2] hag contirared by ${ }^{26} \mathrm{Nl}$ moasurements that the low age of 20.2 ipr is not oimulated by diffusion losses. so tar, however, aystematic study of the inezt gacea of carbonaceous ohondrites has been lacking. This sebed necessary to obtain finter conctustors. In the prenent paper wo prerent maasurewenta of $\mathrm{kg}$, Ho, and Ar in three cl, fourteen C2, six c3, and one c4-type ehondrite fwe have adoptod the claseification by ma schnus and wood [3]] - our study. thus, comprites all but a Fow of the known cacboraceolus chondrites .

The ro-called unequilibrated ordinary chondrites (heraafter abbreviated as voo) are ehondrited with bulk compos-

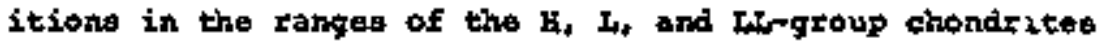




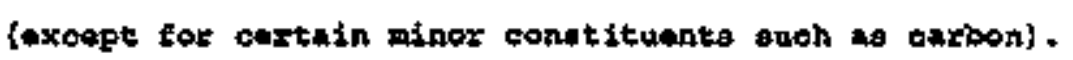
These meteorited are unuual in the following respocts. Uoc show laxge dieperstone of olivine and oxthopyzoxene composttion: thay have well-preserved ehondrites and chondritilc texturep; they frequantly eontain lgneoue glane in chondrules, and they ace gycteratically richer in carbon and

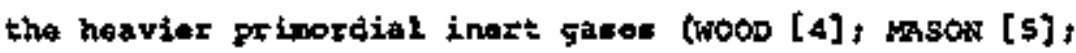
KEIL and FREDFIKSSON [6]; DODD and VAK SGHES [7]; DODD.

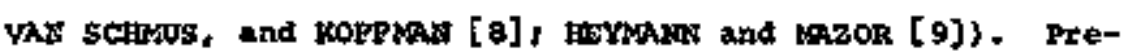
gantly, gon 24 voc are known. Wo have determined the inert gaspa In 12 of thene. With dats available from the work of others (EgERHARD, EUESTER, GEISS, and WARTI [10', GEYMANR

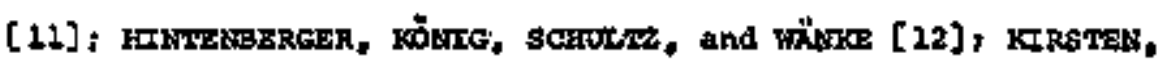

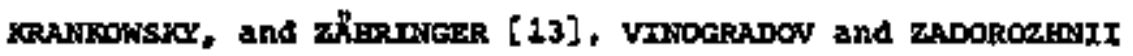
[14]. the number of toc for which rare gas data are available Is thus brought to esventean. Bence, at least tertative coneluatome theuld be poseible.

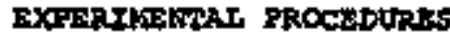

onir procedures have been deseribed

alsewhere in detail. The following are the alient teatures. smatl samples (100 ag, occasionally about $50 \mathrm{mg}$ ) were nelted for gas-axtraction in a molybaenum eructble, which wat placed in a water-cosled anclooure of prrex-glant. The molting lasted for 30 min. During this stage, E, releaced by tho samplen was pumped off through a hot $P A$ barrier. The renaining gas was purified on a hot Ti-gettar. The early removal of $\mathrm{H}_{2}$ yielded conaiderably lower background peake on the maspes 1, 2, and 3.

$A x$ (and the heavier elements $K x$ and $X e$ ) were adsorbed on chareoal at Iiquid $\mathrm{N}_{2}$ temperature wile the isotopis compositions of He and we were determined with the massspectrometer. The absolute quantitieg of these gases were obtained by the nathod of peak-comparison, i.e. metered amounte of "He, "Fe and se (w $704^{20}$ we) were added to the gas extracted from the anples, and the increape of the ion-cuxxent of the nasses 3, 4, and 20 was recorded.

He snd the wore puroped off, and $\mathrm{Ar}$ acimitted to tha massspectromster by warning the charooal up to room temperature. After the leotopic composition was obteinad, the absolute 

(EEYMAan and MAZOR [27]). Fron a simple visual incpection of Nogoya, we concluded that the two portions wore not "eleanly" separated, 1.e. that the "light" portions contain many "dark" Incturions. We gurminad that other carbonaceows chondrites, especially of the c2-variety aight contain similar structures, which have kmained undetected because of the generally dark colour of the carbonaceous chondrites. In the present study, only grall weighte wore available for aspopling. Moreovar, the two samplet of cola sokkeveld camb from two difterant sources; the four Mokele camples cans also from two different sourcer.

The variation of primordial $\mathrm{Ar}$ in the woc is of a fifferent nature [8]. Bere the difterences probably reflect portions with difterent degrees of recrystallization [18]. The two samples of toymka, Bishunpur, and chainpux oom from different sourceg. Aremervorde is probably a "gag-rich" ordinary dhondrite with pample 68 containing a romewhet greatar proportion of "dark" material than sapple 532 (DR. H. Wâkne hax informed ue that his epecimen of aremorvörde is a slear-cut "gall-rich" chondrite).

the duplicate rune chos that the accuzacy for cosmogenic gases such as ${ }^{3}$ He is fair-to-good $\{15-5 \%$. However, there are large variations for cola Bokkeveld $(\sim 25 \%)$ and polten (nearly a factor 2.5), which at present are unexplained. For cold Bokkeveld with only $-0.5 \times 10^{-3} \mathrm{ce} \mathrm{sT2} / \mathrm{g}$ of ${ }^{3} \mathrm{He}$. inaocurate background corxections may be the cause, but this can certainly not be true for pollen.

As customary, wa will use the following aymbols tho subseript always rafwcs to the measured value of a given isotope) to distinguish the three components of the inert gaseb:

a refers to the cosmogenic coraponent

p refters to the primordial component

r refers to the radioganic component

PRTMORDIAL GASES AND DIFPUSTON LOSSES

The calculation of radiation and gas-retention ages is greatly encunbered by the primordial gases, and by the considezation that serious Ho diffusion losses may have occurred for the very finegrained $c 1$ and $c 2$ chondrites. 
The averaste $t$ and Th contents of ordinsry chondrites of 0.01 ppn and 0.04 ppan show that these mateorites could have retalned up to approximately $2 \times 10^{-5}$ ec $\mathrm{STP} / \mathrm{g}^{4} \mathrm{He}$ rince 4-4.5 Gyt ago. Table II glyows the currently known values of the two radioative parents in a fow carbonaceous chondrites; no data are avalable for the voc. but it ig a reasonable assunption that their $U$ and Th contenta are comprrable to those of ordinary chonarites proper. It an be inferred fron Table II that the maximum "He ${ }_{x}^{4}$ contents of carbanaceous chondrites cantiot be groonly different from $2 \times 10^{-5}$ ec sTP/g.

With this criterion the meteorites of rable I fall into two categoriest 1) those that do not eontain detectable anounta of 'the, numbly Bella, cold bokkeyeld, Erakot, Haripura, Kaba, all the $c 3$ and $c 4$ chondrites except vigatano. and all the voc except Bxemervitude (68a)/ and 2) those that certainly contain ${ }^{4}{ }_{\mathrm{He}}$ (all the remaining meteorites). There are considerable aloubts, however, that this sinple divition is tenable. Let us congider the evidence of pigure 1. It if seen that the $c 1$ and $c 2$ chondrites alwhy contain detectable anounte of ${ }^{20}{ }_{\mathrm{Ne}}$, whereas only $1 / 3$ of the remainIng ehondrited do Conly 2 of the voc, aremervobrde and Khohar oontain 20 ve $)$. Even more renarkable to that the ${ }^{4}{ }^{20}{ }^{20}{ }_{p}$ ratio of the c1 and $\mathrm{C2}$ chondrites is always near 200-300, wherass the points of the remaining chanbrites ecatter, aninly above the curve. An especially tolling giece of evidenct is that what is conoidered a genuin. ${ }^{4{ }^{H}} p^{20}$ He ratio in a number of ordinary chondrites ("gas-rich") and enstatite chondrites ia near the value 300 (cf $[16]$ ). Thus, it can be gurnised that 4 te in the $c 1$ and $c 2$ chonarites ia really ${ }_{\mathrm{He}}+{ }^{4} \mathrm{He} \mathrm{c}^{\circ}$

The oxigin of ${ }^{4}$ Ho in Eells, cold Bokkeveld, Erakot, Haripura is, then, anbiguous. In the "gas-rien" chonarites of the el and c2 varieties, and in vigarano, mast of the "не is certainly ${ }^{4}{ }_{p}$ " Hence, we cannot estimate a v. Th-Be age in any of these cases.

A similar ailenta arises for ${ }^{3}$ fe in the carbonaceous chondrutes. Although the ${ }^{4}{ }_{p}{ }^{3}{ }^{3 e}$ ratio in chondrites is known to be large ([16]) HIMTENeERGER, vILCSEK, and WANLE [19]), ${ }^{3}$ He oannot be aeglected hare, esther because ${ }^{3}$ ges is large, or bocause $3^{3}$ He is spall. Moreover, thare ts avidance for diffusion losmes of ${ }^{3}$ He auring or after the exposure era. ANDers [20] hat calculates ${ }^{21}$ we production rates in carbonaceous chondrites, Fron his anta one 
expecte ${ }^{3}$ मе $f^{21}$ Ne of $\sim 20$ in the $c 1$, of $\sim 7.5$ in the $c 2$, of $\sim 6$ in the 63 and 44 chondriteg, and of $\sim 5$ in the voc. These values ard probably on the low slae for the carbonaceous chomarites because of their stasll masses (cf [10]). Anyway, the ${ }^{3}$ He ${ }^{21}$ Ne ratios of Alais, Al kais (632), cold Bokkeveld (673)', Erakot, Knba, Mrghei, Sta, Cruz, ano Grossmaja are at least twice as low as the expected valies shown in Table III. The trut ${ }^{3} \mathrm{He} \mathrm{c}^{21} \mathrm{ke}$ would be lower still if accurate corrections for the prinordisl components could be made, such corrections are intractable, mandy becauce the corrections for ${ }^{3} \mathrm{He}_{\mathrm{p}}$ from ${ }^{4} \mathrm{Ha}_{\mathrm{p}}$ and corrections for Anffusion losges are coupled in an unknown way, becaute the ${ }^{4} \mathrm{He}_{\mathrm{p}}{ }^{3} \mathrm{He}$, ratio seeras to aepend markediy on the proportion of he loot [19], and because the ration of Tabla III are only appraximations.

It if ugeful, however, to calculate ${ }^{3}$ He valuts by neglecting possible diffusion losses. In this senge. they are finimugr values. For the c1 and c2 chondrites, and for vigarano, we have considered 4 tie to be wholly primoratal: a ${ }^{4}{ }_{p}{ }^{3}$ He ratio of 2500 was adopted. No ${ }^{4}$ He is considered to be present in the remaining meteorites. The resulte are thown in colum if of Table 1.
The calculation of ${ }^{21}$ Ne is less ambiguous- cosmogenic noon is known to contain the stable isotopes in nearly equal proportions. Thua a good approximation for

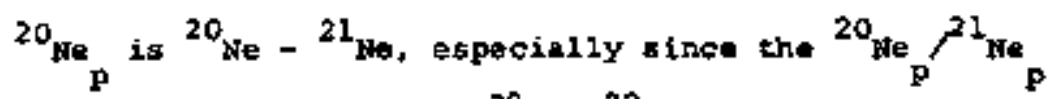
ratio is about 340 . The ${ }^{20}$ te ${ }^{22}$ we ratio in chondrites is knows to vary trom wa -14 , with the larger volues occurring in the so-called "gas-rich" noteorites. The ${ }^{20}{ }_{\mathrm{p}}{ }^{21}$ Ne in chondrites varies also [27]. For chonarites with ${ }_{\text {He }}>10^{-4} \operatorname{cosTP} / g$, we have adopted a value of 354 (the value in the dark portion of Nogoya); for chondzites with 4 He $<10^{-4}$ cesre/g, we have uged the atmospharic ratio of 338 (EBERHAROT, EUSSTER, and MARTI' [21]). Tho sasults are tabulated in colum 12 of Table $I$. Only in Karoonda is ${ }^{36}{ }_{A x}$ greater than $50 \%$. In the remaining chondrites the cosmogenic comportent is msked by $3 \mathrm{~A}_{\mathrm{Ax}}$. Accoraingly, no $3 \mathrm{~A}_{\mathrm{Ar}}$-ages are calculated.

\section{RADIATIOA AGES}

We adopt as our working theory that the anteorites are fragments ejected by impscta from moderately largo parent objects; that the meteorites did not auffer 
aignificant mas-loases after they departed, from their parent objects; and that the average cosmigrray intensity was congtant in space and time during the last 100 Myr. Perhaps the second point is not quite realistic for the friable carbonaceous chondrites. A number of authors conten that spacemerosion is pertinent for stony meteorites. They argue that the cosmic-ray intenaity inside these objects has increased ouring their expogure becaure of the continuous exoaion of the surface by $1 \mathrm{~m}$ pacts of dust, atoms, and ions. space-erosion has probsbly played a minor role for the ordinaxy chondrites and achondxites, but may have been nore important for the carbonaceoul shondrites.

Most vorkers seem to agren that the ${ }^{3}$ He production rate in all varieties of otony meteoriteg is near 2.0 $\times 10^{-8}$ ee 5 re/g per Myr. This value is based on ${ }^{3} H$ moasurements in a number of ordinary chondrites lGeIss. OESCHGER, and SIGKRk [22], GOEBEL and SCHMIDLIN [23]). These maasuramant show that the production rate is

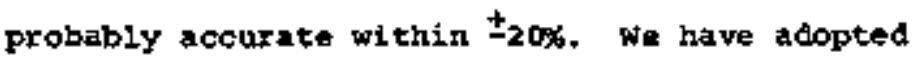
the yalue as shown in rable III. For the ${ }^{2 l} \mathrm{Ne}_{\mathrm{q}}$ production rate in the DOC we have adopted cobB's [24] average value for chondrites, $0.38 \times 10^{-8}$ os ste/g per byr. With this value we have recalculated ANDERs' [20]

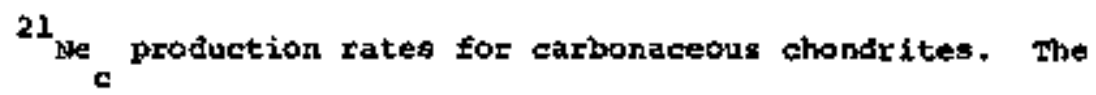
results are showm in Table III. The errors of these production rates cannot easily be ascertained. EBERHAFDrs at al $[10]$ have shown that ${ }^{21}$ de production rates in chondrited vary more than the ${ }^{3}$ He $e$ rates, but their ingenious correlations cannot be used for the carbonaceous chondrites. Judging from $28_{\mathrm{A} 1}$ meagurements by RONE. WA DIHA, and ANDERson [25], it is concluded that variations by $\pm_{50 \%}$ are not uncosmon among ordibary chondrites. If carbonaceous chondrites are genexally as low in mass as their recovered weights setr to suggest (the lergest Lance weighs $52 \mathrm{~kg}$, but $10-100 \mathrm{~g}$ is more typical), sigfificant fluctuations of the ${ }^{21} \mathrm{Me}$ production rates must be anticipated cosmic-ray secondaries escapen more easily from vory small objecta) .

As mentioned in the preceding section, ${ }^{3}$ He $\mathrm{e}^{- \text {gges }}$ were calculated for the cl and the ch chondrites, and for vigarano with the assumption that all ${ }^{4} \mathrm{He}$ is, in fact, primordial. All the remaining ${ }^{3}$ He ${ }^{- \text {-ges were }}$ 
calculated in the ususl way, i. e. ${ }^{4}$ He is considered negligibl*, For Bells, cold tokkeveld, Erakot, Haripura, and kaba ${ }^{3}$ He ${ }_{\mathrm{a}}$-ages were slso calculated on the basis that ${ }^{4}$ He is wholly radiogenic and cosmogenio. In opate moteorites the ${ }^{3} \mathrm{He}$ correction is greater than ${ }^{3}$ He actually present. In aweh wases the ${ }^{3}$ He age is liated as $>0$ wyr. The radiation ages are listed in Toble IV, and are shown in the distcibutions of $\mathrm{g}$ igure 2 .

No distinct trends show up for the three Cl chonarites. As expected, the ${ }^{21}$ He -ages are considersbly greater than the ${ }^{3}$ ite sages. $^{-a g}$

The ${ }^{21}$ we ages of the $c 2$ chondrites range from 0.1 MYr (Haripura) to about $24 \mathrm{MYr}$ (Kaba and Mokoia). The mogt interesting group is the one comprised by borosknno, cold Bokkevela, baxipura, kawapali, and wogora with ages of 0.1-0.6 Myr (Bello perhaps belongs to this category also). Wo other carbonacoous chomarites are found in this age-interval, in fact, smong the several hundreds of ordinary chondrites for which inert gas data are available, there are only four with ages near this interval, and only ono of these, Morland, ia in the intarvol. This is remrkable, and soums to imply that the five earbonaceous chondrites come from a single, or very few collisions. That the ages do not agree with a single value can be due to a number of causes. First, the known masses differ vastly, from $0.03 \mathrm{~kg}$ of Bello to $4 \mathrm{~kg}$ of cold Bokkeveld, Second, the short ages are rather sensitive to exrors is background corractions.

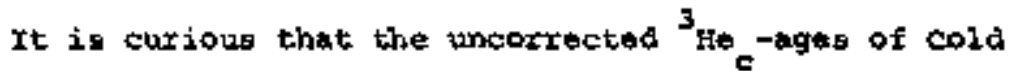
Bokkeveld and Haripura are near $0.2 \mathrm{hyr}$. The ${ }^{21}$ we age of cold gokkevald on the basis of tht data by Kirsten et al [13] is near this value. Ardefs [2]finds an 26 ${ }_{A 1}$-age of $0.1-0.2$ kyr for cold Bokkeveld. He has infoxmed us that wogoya gives an ${ }^{26} \mathrm{Al}$-age of about 0.3 myx, sence, it seems that at least cold Bokk*veld, Haripura, Wawapalt and sogoya come from a single collinion about $0.2 \pm 0.1$ byx ago.

It 1 interasting in this respact that Durfesse and AXDERS [26] have discovered differences in mineralogy which seen to paralled the age-trend. The authors find that the inooluble wimerals of cold Bokkoveld and Haripura (ages $20.2 \mathrm{myr}$ ) consist anong othere of $13 \%$ olivine and $13 \%$ of a magnetic 
spine1, whereas those of Mighei (acte 3 Myr) and Murray (age 4.3 Mrr) contain sos olivine and only traces of epinel. It would be interesting to know whether all the C2 chondxiteg with ages < 1 kyr are of the cold Bokkeveldtype, and thosa with ages $>$ I Hyr of one of nore different types.

Like the aged of the overwhelming majority of the other etony meteorites, those of the cl and C2 chorariteg are several orders of ragnitude saller than the radiation ageg of iron meteofites $(0.2-2.0$ Gyx). Wost authors agree that this implies a different origin, with the stony meteorites coming from objects nearer to the orbit of the Earth. Grossty, the ages of the irong, agree with collision lifetimes of debris from

- Ring asteroide or Mars asteroids, whereag the ages of the stony neteorited are noxe nearly camparable to collision 1ifetimes of debris Erom the woon, or from Apollo asterolds. That the krown carbonaceous chondriter comp to Earth directly frow Mns, on from the distant asterodis can be ruled out on the basis of the present results. The objectione against such an origin of the ordinary chondrttes, stated by ARMOLD [27]. are equaliy, if not more partinent for the c1 and c2 cazbonaceous chondrites, whose ages are always less than 15 Myr the ages of ordinary chondrites range up to sbout $60 \mathrm{myr}$.

It setems thus certain that the c1 and c2 carbonaceous chondritas come ither from the woon, from an apollo asteraid, or perhaps from a comot. A lumar origin of the etony pateorites was first suggested by UREY [29] on the basis of thelc short radiation ages. In one form or another his theory has been adopted by a nurther of workers, whlle others have argued against it; accepting, however, ax they did that certain rare varieties of meteorites such as carbonaceous chondrites might well corae frotw the Hoon (cI [2]). The main objection aganat the lunax origin seens to be that it it sonewhat cificealt to imagine that an impact on the moon could accelecate Fhe friable carbonnceous chondrites to escape-velocities without reofucing them to dust. Perhaps carbonaceous chondrites represent the freakish survivorg of such collisions. 
The ages of the $\mathrm{C} 3$ and $\mathrm{C} 4$ chondrstes present no frech clues. Among the seven oates, thare are no ages

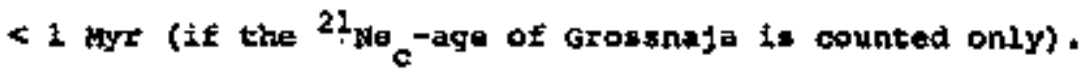
With two ages near so Myr, these meteorited axo mote compurable to the ordinary chondrites in this respect.

No grase aifferences exizt batwen the dgex of the toc and those of the ordinary chondriter proper (F2gure 3). In fact. toc-agos oceut in or meax all of the age-elueteras peaks, or intervals of the ordinary chondrites that have been proposed as having arisen from major impacte, such as at 4-6 and 20-25 hys for the bronzite chondities, or 7-13 and 16-31 kyr for the hypersthene chondrites. It has been suggented by various authors that the voc cone from nearer the surface of chondrite parent objects than ordinary chowdrites proper. HEYMAkt [12] has pointed out that the ordinary chondriter may have come to earth in wo steps. First, they were located on distant asteroids, perbaps one or a fow Mars-aeteroids, which were fragmented by collesions (substantial evidence pointe to a collikion nome 0.5 Gy ago, involving a hyparsthene object). Subsequently, a number of the asteroidal fragmente of the original body, stili of considerable size were deflected by kars into Eazthcroseing orb2ts, wuch as those of the present Apolioasteroidis. Impacts on these fragments produced the meteorites that come to Earth. The fact that uoc are mearly always preeent anong the major age-clusters of the ordinary chondrites saeps to require that the collisions at those times involved the virtual destruction of an Asteroid-fragnent, with meteoritic deloris probuced from what were originally pear-gurface, as well as deepex looatlons of the original Mars-asteroid.

GAS RETENSION AGLS

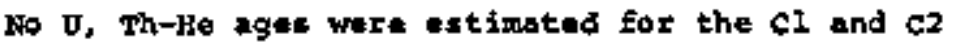
chondrites, for vigarano and aremervörde 686, because part, if not all ${ }^{4}$ He is peimordial. In the tenaining cases, except for Karoonda, I contents. were cansigered 0.011 Ppr; Th contents 0.040 gan leE $[I 1])$. For Karoonda the $J$ and th data of Toble II were used. 4 He was corrected $\operatorname{tor}^{4}$ He with ${ }^{4} \mathrm{He}_{\mathrm{c}} \mathrm{He}_{\mathrm{c}}=5.0[11]$.

$x$ contents for the carbonaceous chondrites ware taked trom [1] except for waxxunton [29]. K contents for the Uoc ware taken from $[B]$. In the case of praifie Dog crask, Sor which no $k$ meneurement was available, a $\mathrm{K}$ 
content of goo ppm was assumed (the overwhelming majority of bronzite and pypersthene chondrites agrea within \pm 10\% of chis value).

The following decay constants were employed: $\lambda\left(\mathrm{U}^{238}\right)=1.54 \times 10^{-10} \mathrm{yr} / \lambda\left(\mathrm{v}^{-135}\right)=9.8 \times 10^{-10} \mathrm{yr}^{-1} ;$ $\lambda\left(\mathrm{Th}^{232}\right)=4.99 \times 10^{-11} \mathrm{yr}^{-1}: \lambda_{x}=0.583 \times 10^{-10} \mathrm{yx}^{-1}$, $\lambda_{\text {自 }}=4.74 \times 10^{-10} \mathrm{yx}^{-1}$

Like the radiation ages, the gas-retention ages shown in Table IV are only rough approxintions. For the woc, which are componitionally comparable to ordinary chondrites proper, the error of the $\mathrm{U}$, Th-He ages from the acopted average $\mathrm{V}$ and $\mathrm{Th}$ contents slone may be as high as $\pm 25 \%$, jugiging from the known $U$ and Th contents of the ordinary chondites. The $U$, Th-He ages of the c3 chondrites may be even more in error, inasmuch as there is no assurance that their $U$ and $T h$ contents are. comparable to those of ordinary chondrites. In fact, the $U$, sh-tie ages of the $c 3$ chondrites axe highly anomalous in that these are sygtematically greater than the $\mathrm{K}-\mathrm{Ar}$ agas. This is unusual because ${ }^{4}$ He aiffuses Easter than ${ }^{40}{ }_{\mathrm{I}}$ in ordinary chondrites, and probably also in the ch chondrites. The systematis affference seens to imply that either the $t$ and Th contents of ch chondrites are substantially greater than 0.011 ppan and $0.04 \mathrm{ppm}$, or that, eontrary to what we have concluded, significant. proportions of ${ }^{4}$ ge in these meteoriter are "He, Although reliable $\mathrm{K}$ measurements are available for most of the chonorftes, it mugt be cautioned that these were always, obtained with different samples than the ${ }^{40}$ Ar data. Por the sake of congistency we have employed $x$ eate for the earbonaceoes chondrites from the wark of one analyst, H. 9. WIIK, whenever possible, His results are always in good agreeruent with those obtained by othere, which seems to imply that $x$ does not vary by much (t) 10-15\% pexhape) in any given carbonaceous chondxite. Amons the K analyses of the toc. five of which are from the work of WITK, only Manych with 1830 ppm is highly unuguel. The remaining values are not inconsistent with the chondritle avarage of about 800 ppp, which seems to imply that the $x$ ata are probably accuzate within $\pm 20 \%$ for our samples. somedution must, howevex, be maintained, espectally for the th3 meteorites which are eompositionally similar to the anphoteric chonaritea. BAIStR and zÄHRINGER 
[30] hrve found vast $k$ variations in the latter.

A survey of the ages (Figures 3 and 4) Ieveals that there is a rough correlation between the types of carbonaceous chondrites and $K-A r$ agest cl meteorites give ages of 1-1.5 GYr, c2 meteorites of 0.6-4.5 GYr, and (c) + c4) of 2-4 Gyc. However, the difference between $c_{2}$ and $1 \mathrm{c} 3+$ c4) is certainly not very pronounced, both varieties contain a subtantial fraction of meteorites with ages only slightly lower tban the accepted age of the solar system. The most consistent theory is that the carbonaceous chondritex were only slightly heated 4.5 Gyt ago, if at all, and that the extremely fine-grained nature of the matrix paterial, which ovidently contains the potassium [1] makes the carbonaceous chondrites especially liable to loge ${ }^{40}{ }_{x_{x}}$ by diffusion. This in turn is consistent with the general evidence for substantial He losses from these meteorites.

We have alrendy mentioned the puzzle that the $\mathrm{U}, \mathrm{Th}$ He ages of the $(C 3+C 4)$ chondriten are atways greater than the $\mathrm{K}-\mathrm{Ar}$ iges.

The great majority of the voc stem to have cooled to below about $200-3000 \mathrm{C}$, the temperature interval in which ${ }^{40}{ }_{A x}$ retention changes tron virtually corplete 1oss to virtusily complete ratention [20], between 4.5 and $2.5 \mathrm{Gyr}$ ago. It is interesting in this respect that the concoxdunt $\mathrm{J}$, Th-He ages (agreenent with K-Ar ages within about $(20 \%$ ) spak for the and general conelusion. Notable exceptions are Barratta, carrawena, and Mezöwadiras, all three of the fol-varipty. (clovis, from the work of hitrenterger et al [12] has a vary low 4 , Th-He age of <0.1 Gyx; obvisouly this moteorite has suifered severe He-losses during the cosmic-ray exposure exa. The $k-A x$ tge of pieschitz, given as 2.66 byx by [10] was recalculated with the $k$-content now available [a]. It has been noted before [11] thet garratta and carraweena sten to have begn definitely involved in collision of a hypersthene parant bbject sowe 500 Wyr ago. HFYMALt" [11] study of the hypers thene chondrites has further shown that the $500 \mathrm{My}$ wollision, while being the nost prominent feature in the $\mathrm{w}$, Th-go age distrbution below 2 Gyr, is certainly not the only catartrophis collision for whach there is ovidence in this time-interval, a Eaw earliar as well as a tew nore recent oolliaions are 1ndigated by the data, but the ages of these are uncertain. 
Mazo-Madaras, and perhape thoher and Fatrejlet, with concoxdant ages of about 1.5, 2,6, and 3.0 Gyr may have been involved in earlier collisons.

The voc open an interasting posoibility fox studying the 3-4 oyr time-interval. It has been argued by various workers that degree of metamorphish 12 related to the depth at which these chondrites found thenselves beneath the surface of the meteorite parent body, i.e. that the least recrystallized and equilibrated ones were nearer to the surface, and vice versa. One would expect that those nearer the surfoce cooled faster, hence show the greater $\mathrm{U}$, Th-ge and $\mathrm{K}$-Ar ages. A test for this hypothesis is show in Figure 5 . The $U$, Th-He ages (Which are more gensitive fndicators of gtorage at higher temperatures than the K+Ax ages) are plotted along the vertical axis. Along the horizontal axis is plotted the quantity "percent mean deviation of olivine" taken from [8]. Phis quantity is proportional to the degree of unequilibration of the ohondrites. There is no trend discernible among the H3 chondrites (clovis must be discounted), However, there is a distinct trend among the $L 3$ chondrites with deczeasing $U$, Th-He ages for increasing degree of equilibration. With only two points. no firm conctudions are possible for the wh ohondrited, however, it is notewortiny that the more equilibrated chondrite parnallee also has the loter $U$, Th-He age. Roughly, ther, one can concluce that the gas-ratention ages are not Inconsfstent with the hypothesis thet the more highly equilibrated ordinary chondrites cone.

on the average, from greater depths in the parent objecta than the more unequilibrated ordinary chondrites, Thin conclusion has interesting inplications for the origin of all these neteorites. 
[1] wasov, B., space Sci, Rav. I (1963) 621.

[2] ANDERS, E., Science 139 (1962) 431.

[3] VAN SCHMUS, W. R., WOOD, J, A. Preprint (1966).

[4] Woop, J. A., Geoch 2 . cospochith. Acts 26 (1962) 739.

[5] MASON, B., Geochim. Cosmochim. Acta 27 (1963) $10 \mathrm{Ll}$.

[6] KEIL, K., FREDRIKSSON, K. Jo Geophys, Research 69 (1964) 3497.

[7] DODD, R, T., VAN SCHMUS, H, R., J, GeOpbys, Reseurch 70 (1965) 3801 .

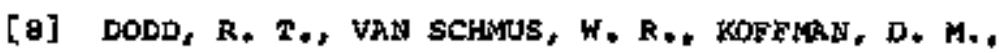
preprint (1966).

[9] HEYMand, D., HRzor, E., science, In press.

[10] EBERkARD, P., EUGSTER, O.. GEISS, J., MARTI, K., z. Naturfor $5 \mathrm{ch}, 21$ a $(1966) 414$.

[11] hEYMANN, D., Icarus, In press.

[12] HINTENBERGER, H., KÖNIG, H, SCHULTZ, I. WÄKKE, H*, z. Naturforsch. 20a (1965) 983 .

[13] KIRSTEN, T., KRANKOWSTK, D., ZḦHRTNGER, J., GeOchim. Cosmochim Acta z7 (1963) 13 .

[24] VIHOGRADON, A. P., ZADOROZHAII, I, X., GoOChemistry (in Rassien) 7 (1964) 587 .
[15] HEYMANN, D., WAZOR, E., J. Geophys. Reseatch 71 (2966) 4695 .

[16] pzPYN, R. O., SIGXER, P., seience 149 (1965) 253 .

[17] HEYMAN, D., MAZOR, E., Pteprint 1966.

[18] VAM SCHmis, W. R., 29th Annual theting of the Meteoritical society, washington D. C., Abutracts (1966)

[19] HINTENGERGER, H., VILCSEK, E., WäkHE, H. Z. Haturforsch. 20a (1965) 939.

[20] ANDERS, E*, space sci. Rev, 3 (1964) 583.

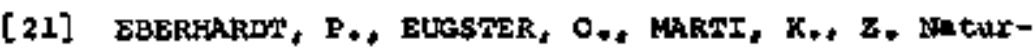
forsch. 20a (1965) 623 .

[22] GEISS, J., OESCHGER, H., SIGNER, P., z, SWturforsch. 1ㅗㅅㅗ (1960) 1116 .

[23] GOEasL, K., sckimitis, P., Z, Naturforech. 15a (1960) 79.

[24] COBB, J. C., Preprint 1965.

[25] ROWE, M. W.., VAI DILUA, M. A., AMERRSON, E* C.. Geochin. Cosmochin, Acta 27 (1963) 993.

[26] DUFRESNE, E.,R., ANDERS, E., Geochim. Coomochim. Acta $\underline{26}$ (1962) 1095 . 
[29] ARptorb, J. R., Astrophys. J. 141 (1955) 1536.

[2日] tRREY, H. 6., J, Geophys, Res, 64 (1959) 1721.

[29] EDwards, G., Geoch1m. Cocmochim. Acta B (1955) 285.

[30] KAISER, W., ZAHERIHGER, J, z, NaturEorsch, 20요

963.

[31] REED, G, W., KIGOSEI, K, TURKEVICH, A., Geogh1m, Cosmochim. Aeta 20 (1960) 122 .

[32] GOLES, G, G., AKDERS, E,, Geochim. Cosmoshim, Acta 26 (1962) 723 .

[33] LONERIHG, J, F., MORGAY, J. H., J. GeOphys, Resenzch 69 (1964) 1979 .

[34] ZÄHRIMGER, J. Preprint 1965.

ACKGOTALDOEHENTS

We thank Dra. A. R. Aldexman, E. Andars, t. L. Krinov, B. Masan, C, B. Moore, E, I, Olsen, W. R. Von schors, and $J$. A. Hood for making the samples avallable. This work was supported by the U. S. Hational Aeronauties and space Adminlstration grant Neg-366 and by the U. S. Atomis Energy comaisaion, Contract AT $(11-1)-382$. 
Table I. Inert Gas contents of carbonaceous chondrites and Unequilibrated Ordinary Chondriteg. Units $10^{-1} \cos T / 9$.

\begin{tabular}{|c|c|c|c|c|c|c|c|c|c|c|c|c|}
\hline & & Run & 3 [1] & $4_{\text {He }}$ & 20 & $21_{\text {椙 }}$ & 22 & ${ }^{36} \mathrm{Ax}$ & ${ }^{36}{ }_{A x}$ & ${ }^{40}$ Ar & ${ }_{\text {tie }}^{3}$ & $2 l_{\mathrm{C}}$ \\
\hline \multicolumn{13}{|c|}{ Carbonaceous chondrites } \\
\hline$c 1$ & $\begin{array}{l}\text { Alais } \\
\text { Ivuna } \\
\text { Orgueil }\end{array}$ & $\begin{array}{l}639 \\
645 \\
644\end{array}$ & $\begin{array}{l}4.6 \\
5.5 \\
6.1\end{array}$ & $\begin{array}{r}4.370 \\
9.430 \\
10.900\end{array}$ & $\begin{array}{l}14.3 \\
34.6 \\
31.2\end{array}$ & $\begin{array}{l}1.5 \\
0.50 \\
0.80\end{array}$ & $\begin{array}{l}3.3 \\
4.0 \\
4.3\end{array}$ & $\begin{array}{l}50 \\
82 \\
77\end{array}$ & $\begin{array}{l}9.6 \\
17.2 \\
15.9\end{array}$ & $\begin{array}{l}386 \\
337 \\
518\end{array}$ & $\begin{array}{l}2.9^{b} \\
1.7 \\
1.9^{b}\end{array}$ & $\begin{array}{l}1.46^{\circ} \\
0.39^{\circ} \\
0.71\end{array}$ \\
\hline$c 2$ & $\begin{array}{l}\text { Al Rais } \\
\text { gells } \\
\text { Borlskino } \\
\text { Cold gokkeveld } \\
\text { Cold Bokkeveld } \\
\text { Erakot } \\
\text { Haripura } \\
\text { Kaba } \\
\text { Kaba } \\
\text { Mighei } \\
\text { Mokoia } \\
\text { Mokoia } \\
\text { Hokoia } \\
\text { Mokoia } \\
\text { Murray } \\
\text { Nawapall } \\
\text { Nogoya-1ight } \\
\text { Nogoya-dark } \\
\text { Pollen } \\
\text { Follen } \\
\text { sta. Cruz } \\
\text { Sta. Cruz }\end{array}$ & $\begin{array}{l}632 \\
691 \\
683 \\
639 \\
673 \\
681 \\
635 \\
631 \\
646 \\
640 \\
633 \\
641 \\
674 \\
680 \\
643 \\
637 \\
670 \\
671 \\
647 \\
690 \\
636 \\
650\end{array}$ & $\begin{array}{c}11.3 \\
0.02 \\
4.8 \\
0.44 \\
0.56 \\
5.3 \\
0.45 \\
3.7 \\
4.5 \\
2.1 \\
56 \\
56 \\
52 \\
54 \\
13.1 \\
9.2 \\
1.1 \\
16.0 \\
25.6 \\
9.0 \\
5.3 \\
5.0\end{array}$ & $\begin{array}{r}3,180 \\
15 \\
11,800 \\
1,760 \\
2,024 \\
1,890 \\
2,500 \\
1,930 \\
2,770 \\
3,960 \\
89,400 \\
96,300 \\
94,600 \\
81,200 \\
31,400 \\
28,500 \\
4,270 \\
49,300 \\
22,000 \\
15,600 \\
3,450 \\
3,370\end{array}$ & $\begin{array}{c}18.2 \\
0.75 \\
55 \\
7.2 \\
7.6 \\
8.9 \\
7.9 \\
11.2 \\
14.1 \\
14.2 \\
352 \\
301 \\
285 \\
208 \\
151 \\
125 \\
17.4 \\
252 \\
87.0 \\
87.4 \\
12.5 \\
1.3 .5\end{array}$ & $\begin{array}{l}3.3 \\
<0.01 \\
0.33 \\
0.10 \\
0.15 \\
1.6 \\
0.05 \\
3.5 \\
3.7 \\
0.75 \\
4.3 \\
5.3 \\
3.6 \\
2.8 \\
3.6 \\
0.43 \\
0.12 \\
0.80 \\
0.60 \\
0.70 \\
1.6 \\
1.7\end{array}$ & $\begin{array}{l}5.6 \\
0.08 \\
5.3 \\
0.90 \\
1.0 \\
2.8 \\
1.0 \\
5.0 \\
5.5 \\
2.5 \\
31.0 \\
28.6 \\
25.8 \\
18.9 \\
14.3 \\
10.9 \\
1.9 \\
21.6 \\
8.0 \\
7.0 \\
3.1 \\
3.4\end{array}$ & $\begin{array}{l}38 \\
12.2 \\
46.4 \\
17.8 \\
12.0 \\
37.5 \\
31.5 \\
25.0 \\
24.8 \\
58.6 \\
19.0 \\
27.2 \\
22.5 \\
16.5 \\
29.9 \\
26.0 \\
14.2 \\
58.1 \\
72.2 \\
77.1 \\
40.4 \\
58\end{array}$ & $\begin{array}{r}9.0 \\
2.3 \\
9.0 \\
3.5 \\
3.0 \\
8.2 \\
6.3 \\
5.7 \\
6.9 \\
11.5 \\
3.8 \\
6.1 \\
4.7 \\
3.9 \\
19.2 \\
6.2 \\
3.1 \\
12.6 \\
17.0 \\
14.6 \\
8.5 \\
13.3\end{array}$ & $\begin{array}{r}1,420 \\
3,400 \\
610 \\
294 \\
235 \\
1,250 \\
576 \\
784 \\
390 \\
1,490 \\
1,170 \\
1,170 \\
1,330 \\
1,010 \\
805 \\
390 \\
473 \\
1,400 \\
546 \\
603 \\
= \\
1,360\end{array}$ & 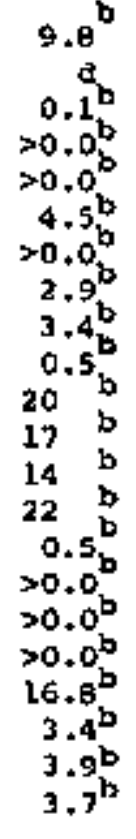 & $\begin{array}{c}3.25^{\mathrm{a}} \\
\mathrm{d}^{\mathrm{f}} \\
0.17^{\mathrm{f}} \\
0.0 \mathrm{~g}^{\mathrm{e}} \\
0.23^{\mathrm{e}} \\
1.58^{\mathrm{e}} \\
0.03^{\mathrm{e}} \\
3.48^{\mathrm{e}} \\
3.67^{\mathrm{e}} \\
0.71^{\mathrm{e}} \\
3.27^{\mathrm{f}} \\
4.47^{\mathrm{f}} \\
2.77^{\mathrm{f}} \\
2.22^{\mathrm{f}} \\
1.16^{\mathrm{t}} \\
0.05^{\mathrm{f}} \\
0.07^{\mathrm{e}} \\
0.06^{\mathrm{f}} \\
0.35^{\mathrm{f}} \\
0.45^{\mathrm{f}} \\
1.56^{\mathrm{G}} \\
1.66^{\mathrm{e}}\end{array}$ \\
\hline
\end{tabular}


Page - 2 (continued)

Tablo I. Inert Gag contents of carbonactous chondrited and trequilibrated ordiary chondrites. Units $10^{-8} \operatorname{cosTP} / 9$

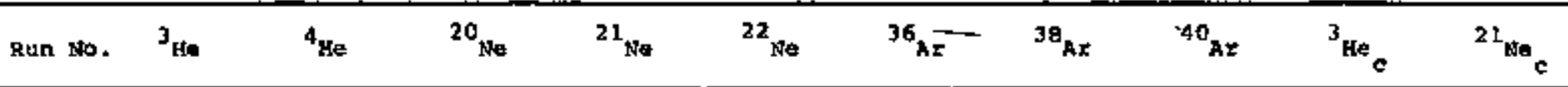

Carbonaceous Chondrites

c3

Felix
Gossnaja
tench

ormans

vigarano

Warrenton

c4

Karconda

Karaonda

652
+653
649
634
654
649

630

657

912,500

912,500

$6.31,630$

$37 \quad 2,400$

B.3 4,450

$50 \quad 2,200$

BS

B3

2, 660

\section{6}

\subsection{1}

7.1
5.3

5.3
6.3

16.1

16.1

15.2

17.7

0.60

1.6

4.8

1.8
7.4

15.9

1.9 .9
24.9

16.9

14.8

\subsection{4}

2.1

5.9

3.2

9.5

18.5

16.8
$118 \quad 23.8$

137

5?

31.0

103

3.8

4.3 $\begin{array}{r}4.9 \\ \hline\end{array}$

26.3

11.0

6,2

20.4

2.7

2.1
2,300

797

1,690

2,250

2, 240

2,830

1.390

1.430
915

$1.2^{\circ}$
$6.3^{4}$

$37^{6}$

6. $3^{c}$

$\mathrm{sa}^{\mathrm{c}}$

85

git $15.2^{\circ}$

$0.60^{\circ}$

1.6

4.9 \%

$1 . g^{\mathrm{e}}$

$16.8^{\circ}$

thequ\$11brated oxdinary

chondrites

t13

Bremervörde
Bremervörde
Pralrie Dog creek

686

$20.6 \quad 2,370$

$21.7 \quad 4.200$

$44 \quad 1,520$

10.2

7.4

4.3

3.8

5.4

10.1

2.5

1.4

a 9.1

5.4
0.4

e.4

2.3

2

$20.6^{c}$

$217^{7}$

$4.3^{6}$

$42 \quad 2,030$

$50 \quad 2,370$

$13.2 \quad 1,680$

$14.7 \quad 1,700$

$15.0 \quad 600$

16.0

52

6.9

16.0

a 64

13.2

8.1

$4.1 \quad 3.7$

$6.6 \quad 3.2$

12.6
3.3

3.3

37

60

39

11.6

7.7

$4.5 \quad 2.4$

$27.3 \quad 6.0$

$11.1 \quad 11.1$

$4.1 \quad 3.0$

$2.8 \quad 15.6$

B.3 25.6

$12.7 \quad 16.3$

3.3

$\begin{array}{lllll}200 & 4.6 & 3.0 & 4.2 & 4.9\end{array}$

3.9

3.3

5,3

4.3

0.93

1.2

.
4,070
3,930
4,830
1,830
660
600
$37 \%$

$42^{\circ} 9.2^{\circ}$

$50^{\circ} \quad 11.5^{\circ}$

$13.2^{\circ} \quad 3.7^{\circ}$

$14.7^{\mathrm{C}} \quad 3.2^{\mathrm{e}}$

$15.0^{\circ} \quad 2.4^{\circ}$

$16.0^{\mathrm{c}} \quad 6.0^{\circ}$

$52 \mathrm{e}^{\circ}=11.1^{2}$

garratta

687

4.6

(2)

1.2

$\begin{array}{ll}1 . & 3.0^{\circ} \\ 1 & 3.0^{\circ}\end{array}$ 


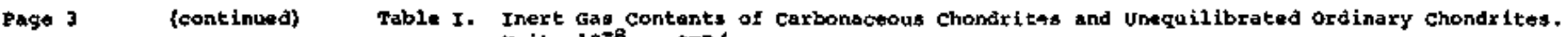
Unit: $10^{-8} \cos 2 / g$

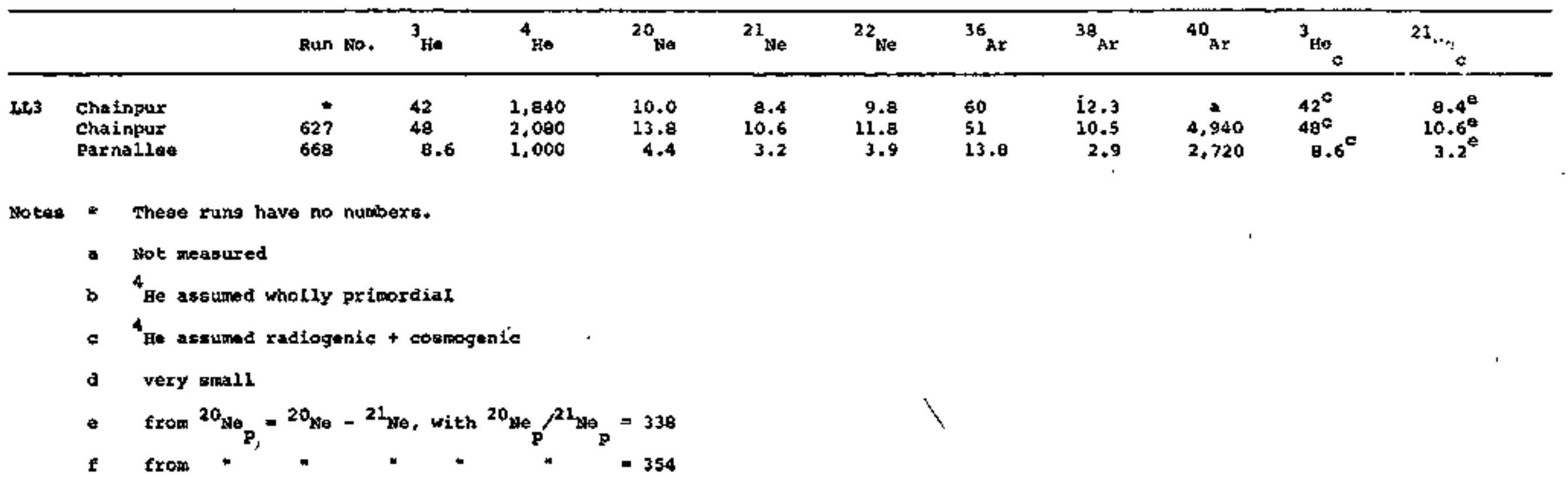

able II

Uraniun and Thorium contants of Carbonaceous Chondrites

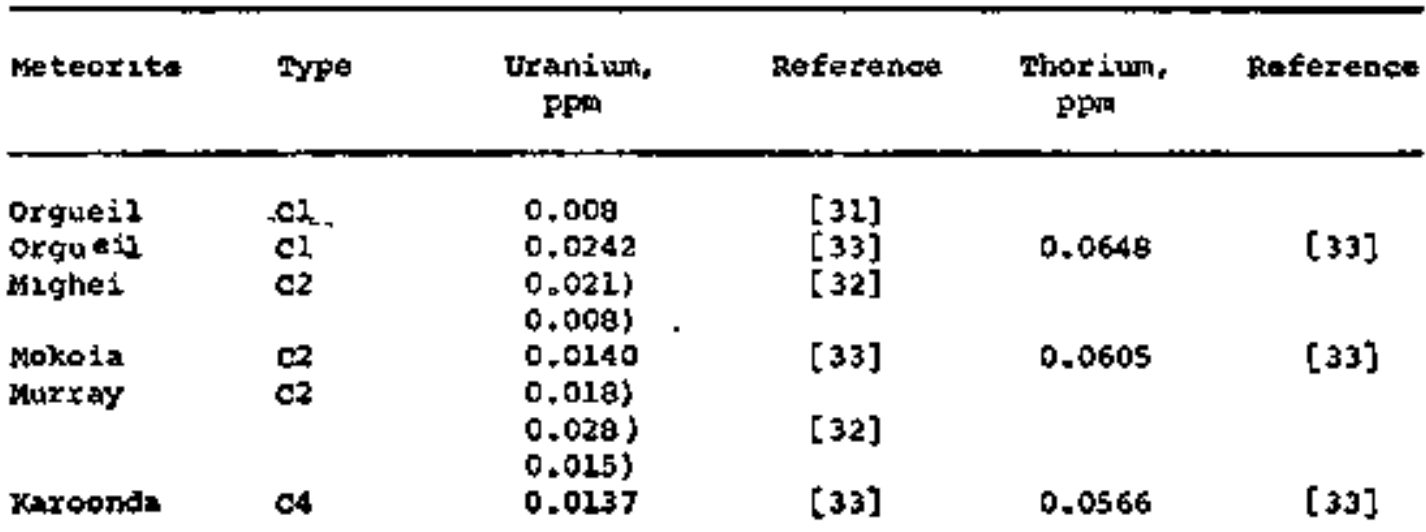




\section{Table III}

Production Rates of ${ }^{3} \mathrm{He}_{\mathrm{a}}$ and ${ }^{2 I} \mathrm{Ne} \mathrm{c}^{2}$ urits $10^{-8}$ cesre/g per Mr

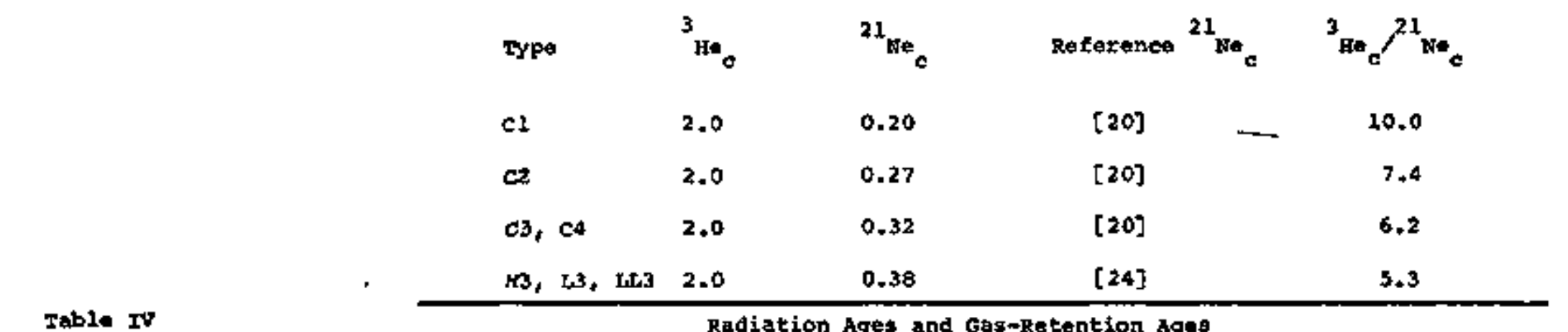

Tab1e IV Radiation Ages and Gasmetention ages

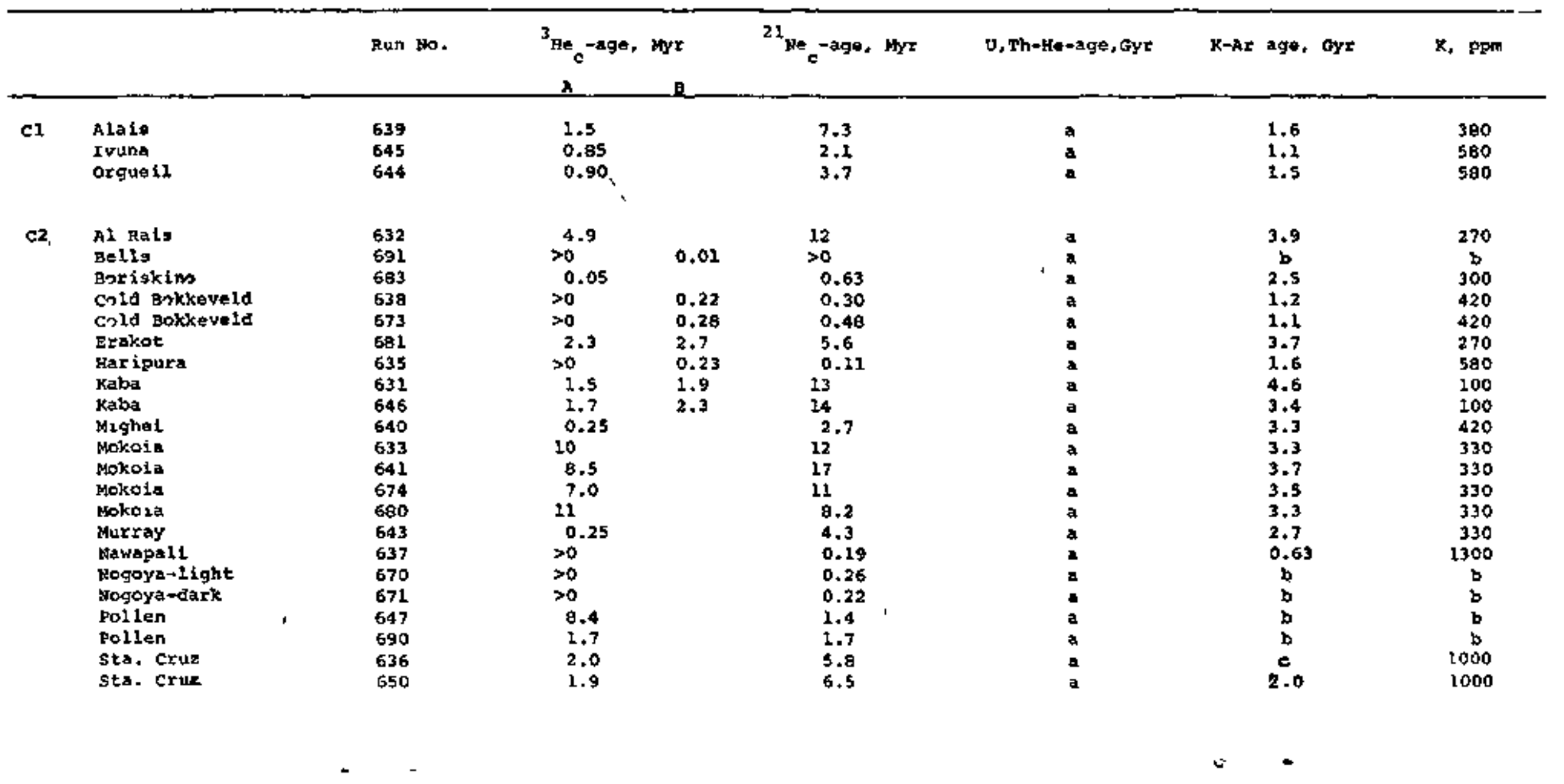


Table IV

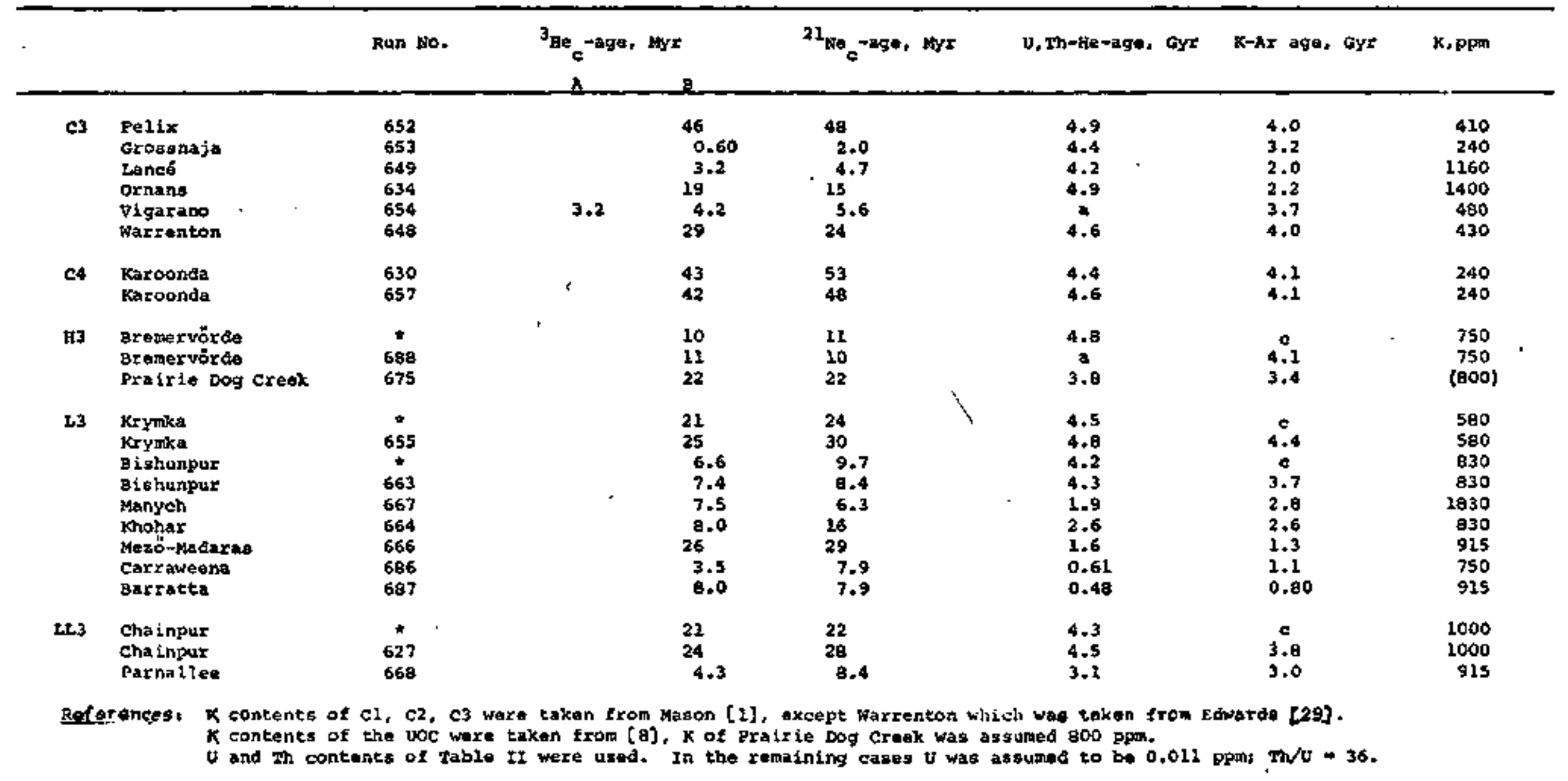

Noteses At age enlevlated with the assumption that 4 He is wholly primordial

8: ate calculated with the assumption that 4 is te radioganis and comogenic

a; tie detinitely or probably prinordial

b: no kodate atailablo

of no $\mathrm{Ar}$ velues available. 


\section{FIGURE CAPTIOHS}

Pig 1. 4to va ${ }^{20} \mathrm{He}_{\mathrm{p}}$ for the meteorites of rable I. open clrcless (Cl + C2) chondrites. Filledin eirelest $(\mathrm{CH}+\mathrm{C} 4)$ chondytess and unc. solid linos ${ }^{40 / 20}{ }^{2} e_{p}=250$. wote that all the cl and C2 chondrites agras closely with thls ratio. The points along the 2aft vertical axie ropmant chondrites with ${ }^{20}{ }_{P}<1.0 \times 10^{-8}$ ccstp/g.

71g 2. Radiation ages of carbonaceous chondrites and of woc. Open aymbols: average of ${ }^{{ }^{H}}{ }_{c} c$

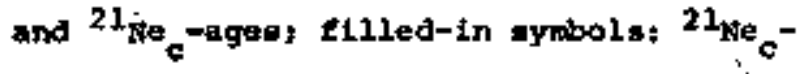
oge onfy. Circles: inert gas data from the pregent work, triangles: inert gas eeta from $[10],[12]$, and $[34]$.

P1g 3. U. Th-He ages of carbonaceous chondritess and of Joc. Open symboles aiscordant ages, filled-in symbols: consordant ages; starced symbols: no ${ }^{40}$ Ax data available. circles: inert gas data from the present work, triangleat inert gas data from (10). [12], and [ 34].
Pig 4. K-Nr ages of earbonaceous chondritan and of woc. Circlas: inert gal data from the present work; triangles: lnert gas data fron $[10]$. [12], and [34], symbol $\mathrm{x}$ rakers to kaba.

Fig 5. V. Th-fie ages (froma Figure 3) of the voc versus "percent mean devintion of olivine",

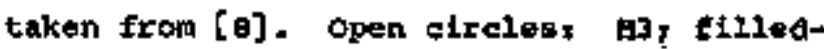
In circles: 23: trianglen: wh chondritea. settering; BA = Barratta, BI - Bighumpur, BR - Bromerpörde, CA= carraweena, GH = chaingur; th - clovis; $\mathrm{kH}=\mathrm{K}$ Kohax; $\mathrm{KR}=$ Krytuka, Ma = Manych: MN - Mezö-Madaras: PA - Faxnalleef PDC - Prairie Dog Ereek, TI a rieschitz. 

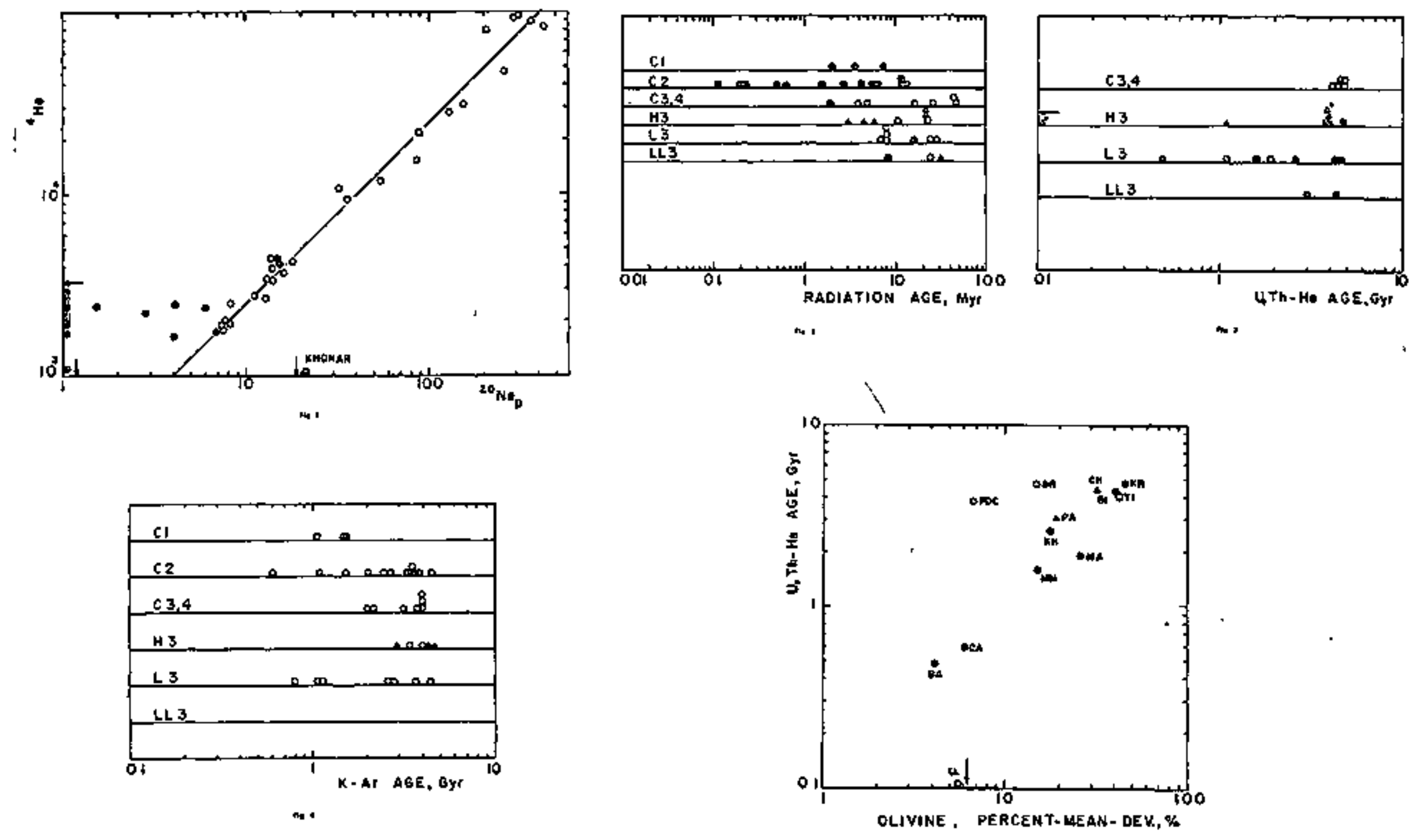

$\rightarrow$ 